\title{
Input Use and Cost of Cultivation of Sugarcane - A Study in Telangana Region of Andhra Pradesh
}

\author{
Dr. Ankasala Samba Siva Rao \\ Faculty, Department Of Economics, Kakatiya University, Warangal, Ts.
}

\section{Introduction}

Sugarcane Is An Important Commercial Crop Of The World And More Than 100 Countries Produce Sugar, At Present Brazil, Cuba, Mexico And Thailand Are The Leading Producers Of Cane Sugar, 78 Per Cent Of Which Is Made From Sugarcane, Grown Primarily In The Tropical And Sub-Tropical Zones Of The Southern Hemisphere. Currently 69 Per Cent Of The World's Sugar Is Consumed In The Country Of Region. Globally, Sugarcane Is Cultivated Over An Area Of 20.10 Million Hectares With A Production Of 1,318.10 Million Tones And Productivity Of 65.5 Tones Per Hectare. Sugarcane Area And Productivity Differ Widely From Country To Country. Brazil Has The Highest Area (5.34 Million Hectares) While Australia Has The Highest Productivity (85.1 Tones Per Hectare) ${ }^{1}$.

India Ranks Second Among The Sugarcane Growing Countries Of The World In The Both Area And Production After Brazil With An Area Under Sugarcane Cultivation Of 4.94 Million Hectares (2010-11) With An Average Yield Is 68.6 Tones Per Hectare. The Production Of Sugar Has Witnessed A Dramatic Increase To Around 24.3 Million Tones During The Same Year. The Recovery Rate Per Tone Of Sugarcane Is 10.17 Of Sugar In India ${ }^{2}$.

India Producing Sugar From Cane Ranks Second Among Sugar Producing Countries By Contributing 15 Per Cent In White Crystal Sugar Production Of The World Share. Other Important Sugar Producing Countries Of The World Are Brazil, Thailand, Pakistan, Cuba, Mexico, Colombia, Australia, Usa, Philippines And Indonesia ${ }^{3}$.

Indian Sugar Industry Has A Unique, Intrinsic And Symbolic Relationship With The Livelihood Of The Rural Masses And Contributes Around 2 Per Cent To The National Gross Domestic Product. It Employs Over 40 Million Cane Growers And Their Families, Constituting 7 Per Cent Of The Rural Population And About 3.5 Lakh Skilled And Unskilled Labourers. As A Raw Material, Sugarcane Is Transported From Farms To Sugar Mills And Hence The Service Sector Like Transportation Is Getting Developed In Addition To Rural Road Development. Sugarcane Is The Basic Raw Material For Gur Making, And Gur Making Is One Of The Important Cottage Industries. The Area Under Sugarcane Has Gradually Increased From 2.7 Million Hectares In 1980-81 To 4.9 Million Hectares In 2010-11, Mainly Because Of Much Larger Diversion Of Land From Other Crops To Sugarcane By The Farmers For Economic Reasons From A Level Of 154 Mmt In 1980-1981, The Sugarcane Production Increased To 241 Mmt In 1990-1991 And Further To 342 Mmt In 2011-2012.

Sugar Production In India Reached 28.36 Million Tones In 2006-07 It Is Peck Level But The Following Years Are Gradually Up And Down Situations Are Happened, On Account Of Drought And Pest Infestation In Certain Major Sugar Producing States ${ }^{7}$. It Is 26.35 Mmt In 2007-08, 14.53 Mmt In 2008-09, 18.91 Mmt In 2009-10 In The Recent Year 2010-11 Increased By 24.39 Mmt ${ }^{5}$.

In 2010-11, There Were 671 Installed Sugar Factories Are In The Country Of Which 527 Are Working With A Production Capacity Of 243.94 Lakh Mts Of Sugar. These Mills Are Located In 18 States Of The Country. Around 322 Of The Total Installed Mills Are In The Private Management, 297 Factories Are Under Cooperative Sector And 52 Factories Are In The Public Sector. The Number Of Factories Are In The Private Sector Has Increased Day By Day, Which Shows The Corporatization Of Sugar Production. Maharashtra Has Been The Most Enterprising Of The States In Starting New Factories Which Increased From 102 In $2004-05$ To 167 In $2010-11^{6}$.

The Total Area Under Sugarcane Cultivation In The State Of Andhra Pradesh Has Come Down From 2.5 Lakh Hectares In 2007 - 08 To 1.58 Lakh Hectares In 2009 - 10 But It Is Increased To 1.90 Lakh Hectares In 2010 - 11 And Again It Was Reduced To 1.80 Lakh Hectares In The Present Year. This Is Quite Alarming Drop In The Area Of Cultivation. Besides The Productivity In The Available Land Is Either Stagnant Or Low Making It A Completely Non-Profitable Venture For A Sugarcane Farmer. This Will Impact The Sugar Industry. A Recent Fao Report Predicts A Sharp Fall In Sugar Production In India In The Year Of $2009^{7}$

Growth Performance Of The Agriculture Sector Of Andhra Pradesh Is Examined For The Long Period Of 44 Years (1955-56 To1998-99) With A Break Up In To Four Periods. The First Sub Period Extending From 1955-56 To 1969-70, Is The Pre-Green Revolution Period. The Second And Third Sub Periods, Covering Seventies And Eighties, Represent First And Second Phases Of Green Revolution. The Fourth Sub Period Of 
Nineties Is The Period Of Economic Liberalization. Growth Rates Of Production, Area And Yield Of Important Crops Are Estimated From A Single Long Linear Trend Education With Dummies For Separating The Growth Rate Of Each Sub Period. The Intra-State Analysis Focused On The Six Agro-Climatic Zones In The State ${ }^{8}$.

The Region - Wise Area And Out Turn Of Sugarcane Production Of Andhra Pradesh Is Presented In Following Lines. The Total Area Under The Cane Production In 1991- 92 Is 2,02,200 Hectare And Its Out Turn Is 15,15,667 Thousand Tonnes. Of That Coastal Area As About 60 Per Cent Of Area And Its Out Turn Around 58 Per Cent Of Cane Production, In Telangana It Is 26.00 Per Cent Area And Around 27.00 Per Cent Of Cane Production And In Rayalaseema 15.00 Per Cent In Area And Cane Production. In 2005 - 06 The Total Area Under Cane Production Of Andhra Pradesh Is 2,29,960 Hectares And Its Out Turn Is 18,69,878 Thousand Tonnes. Of That, Coastal Area Is About 67 Per Cent In Area And 62 Per Cent In Cane Production, In Telangana It Is 22 Per Cent Area And Around 25 Per Cent In Cane Production And In Rayalaseema 11 Per Cent In Area And 13 Per Cent Cane Production. In The 15 Years Duration The Area Under Sugarcane Cultivation And Its Out Turn Slowly Increased, In The Region-Wise The Coastal Area Has Gone Up 7 Per Cent In Acreage And 4 In Production. In Telangana Region There Is A Downfall In Both Area And Acreage I.E. 4.00 Per Cent In Area And 2.00 Per Cent In Production. In Rayalaseema Region There Is A Downfall In Acreage And Production I.E. 3.00 Per Cent And 2.00 Per Cent. From The Above Analysis It Is Clear That There Is A Growing Tendency In All Regions But The Production Efficiency Of Sugarcane Production Is More In Telangana Region 2005 - 06. And It Is Observed That During The Period 1 To 15 Years The Production Efficiency Of The Coastal Region Is Much Better Than That Of Other Regions Of Andhra Pradesh'.

Deolalikar, A. B. (1981) Examined The Productivity And Farm Size For India, For The Years Of 1962 - 72 By Using Simple Regression Model. The Major Finding Of This Paper Was That The Small Farm Sector As A Whole Enjoyed Higher Yield Per Unit Of Land Than The Large Farm Sector In Indian Agriculture But The Yield Advantage Of Small Farm Sector Diminishes And In Fact Even Reverse With The Technical Change In Agriculture ${ }^{10}$

Salam. A, (1976) Examined Factor Inputs Used And Farm Productivity On Different Farms Categories In Punjab For The Time Period Of 1976 By Using Multiple Regression Model That Small Farmers Used Higher Amounts Of Factor Inputs The Inputs, Which He Used Did Not Appear To Be Significant Among Various Farm Size Categories. The Farmers Operating Small Farms Were Obtained Lower Crop Yields. This Trend Was More Pronounced In Case Of Mix-Pak Wheat. Owner Operated Farms Generally Obtained Higher Per Acre Yields Than Tenant Operated Farms ${ }^{11}$.

C.H. Hanumantha Rao's (1965), In His Study, On Agricultural Production Functions, Costs And Return In India, Stated That "With Labour-Intensive Techniques, Productivity Of Land And Output Can Be Railed Bent Under A More Even Distribution Of The Ownership Of Land Which Would Make For A Greater Identity Between These Three Factors (I.E., Ownership, Management And Work). The Question Efficiency Of Small Peasant Farms Needs To Be Explored Further Not Only From The Point Of View Of Output Maximization But Also From The Point Of View Of Surplus Generation For Economic Development ${ }^{12}$.

The Similar Views Were Also Expressed By S.K. Chakravarthy (1972) That Even The Small Cultivators With Operational Holdings Below 5 Acres May Stand Viable With Positive Saving And Net Investment Provided Sufficient Market Orientation And Irrigational Facilities Extended To Them ${ }^{13}$.

R.B. Parthasarathy And K.S.P. Satyanarayana (1976) Pointed Out That The Losses And Profits Differed From One Region To Another. Their Analysis Showed That In 1965-66 Cane Growers In North And South Circars Were Incurring Losses In Sugar Cane Farming When Compared With Farmers In Telangana, Who Were Making Profits. But The Increase In Input Costs Had Increased The Cost Of Cultivation In All The Regions And Cane Growers In 1970-71 Were Making Profits In South Circars And Telangana, While The Losses Were Minimized In The Case Of Cane Growers In North Circars ${ }^{14}$.

V.K.R.V. Rao, (1978) Also Stated That The Technology Is Not Neutral To Scale And That Some Of The Inputs Are Indivisible And Are Beyond Small Farmers' Capacity ${ }^{15}$.

When We Look Into The Analysis Of Prof. C.H. Hanumantha Rao, (1979) It Is Found That The Farmers With Resource Endowments Are Adopting More Capital Intensive Techniques. The Differential Gains To Different Inputs Had Been Stressed In Various Studies. And He States That Although Hyv And Fertilizers Are Neutral, They Are Not Resource Neutral. Since Large Farmers Have Better Command Over Resources And Their Risk - Bearing Have Greater Capacity And So They Adopt Capital Intensive Techniques ${ }^{16}$.

K.S. Pradeep And E. G. Heady, (1983) In The Developing Countries Like India There Is Every Need To Strengthen The Small-Scale Agro Based Industries Not Only To Provide Large Scale Employment But It Is Also Help To Increase The Productivity Of The Labour. Therefore Study On Farm Size And Productivity In A Crop Farming Area Of West Bengal Has Mentioned That Farm Size And Distribution Of Holding Bear Significantly On Farm Productivity Particularly Reorganization Of Agriculture Through Reduction In-Equity Of Distribution Of Land Holding Consolidation Policies Are Expected To Enhance Farm Productivity. Further, A Policy Of Shifting Labour From Farming To Rural Based, Small-Scale Agro-Industries Could Help 
Agricultural Productivity And Income. This Policy Could Generate Income To Accelerate Capital Formation $^{17}$.

Accumulation Of Capital For Agriculture Operation Is Still A Problem For Small Farmers. R.K. Patel And A.C. Gangwar, (1983) Expressed That Technology And Capital Play Vital Role In Increasing Farm Earnings And Employment On All Size Of Farms. Particularly Capital Is Scarce Resource For The Small Farmers And They Used It Effectively And Could Increase Their Profits. Technology Also Has Been Found To Increase The Net Income Of Small Farms Followed By Medium And Large Farms ${ }^{18}$.

The Sample Districts Of Telangana Area Under Sugarcane Cultivation And Its Production Are Nizamabad And Khammam For The 15 Years Period (1991 -92 To 2005 - 06). The Table Analyzed That The Total Area Under The Cane Production Of Telangana Region In 1991- 92 Is 53,111 Hectare And Its Out Turn Is 4,03,822 Thousand Tonnes. Of Which The Sample Districts Of Nizamabad Around 40.00 Per Cent In Each Of Acreage And Production And Khammam Around 5.00 Per Cent In Each. In 2005 - 06 The Total Area Under Cane Production In Telangana Region Is 49,622 Hectares And Its Out Turn Is 4,65,923 Thousand Tonnes. Of That Nizamabad District Cane Acreage Is About 31.00 Per Cent In Each Area And Cane Production 30.00 Per Cent. In Khammam District Around 7.00 Per Cent In Each In The 15 Year's Duration The Area Under Sugarcane Cultivation Slowly Decreased But In Out Turn It Is Slowly Increased In The Region. The Khammam District Area Has Gone Up Around 2.00 Per Cent In Each. In Nizamabad District There Is Downfall In Both Area And Acreage I.E. 10.00 Per Cent. We Can Safely Conclude That Khammam District Is More Efficient Than The Other Sample District I.E. Nizamabad ${ }^{19}$.

\section{Methodology}

The Database For The Study Comprises Data Collected From Primary And Secondary Sources. The Primary Data Were Collected In 2006-07 Through Administering The Structured Questionnaire. The Questionnaire Was Prepared And Applying Random Sampling Choosing 150 Samples From Each Sampling District Of Nizamabad And Khammam. The Samples Were Chosen To Represent Four Categories Of Sugarcane Growers From Each District. The Categories Are Based On Their Landholdings Viz (I) Marginal Farmers Owning Less Than 2.5 Acres (M.F), (Ii) Small Farmers Owning Between 2.5 To 5 Acres (S.F), (Iii) Medium Farmers Owning Between 5 To 10 Acres (Med.F), (Iv) Large Farmers Owning More Than 10 Acres (L.F). The Data Collected Was From Fresh Plantation Of Sugarcane Crop. The Secondary Data Consisted Of The Published Reports On The Sugar Cane Production In India And Andhra Pradesh And Will Be Examined For The Two Districts I.E. Khammam And Nizamabad Districts Of Telangana Region In Andhra Pradesh. Books, Publications And Articles Are Also Have Been Referred.

\section{Objectives Of The Study:}

1. To Make An Analysis Of The Cost Of Cultivation Of Sugarcane Per Acre.

2. To Find Out The Relationship Among The Factors Of Production Of Sugarcane Cultivation

\section{Sources Of The Data:}

1. This Study Uses Primary And Secondary Data.

2. Primary Data Is Collected From The Respondents Of The Sample Villages Of Khammam And Nizamabad Districts Through Administering Questionnaire.

3. The Secondary Data Included Books Journals And Periodical Publications Such As Season And Crop Reports Published By The Bureau Of Economics And Statistics, Govt. Of A.P., And India, Publications Of National Institute Of Rural Development, Economic And Political Weekly, Indian Journal Of Agricultural Economics, Survey Of Indian Agriculture Published By The Hindu And Some Internet Web Sites Etc.

\section{Sample Design Of The Study:}

The Sample Design For This Study Is Selected As One Of The Multi Stage Stratified Random Sampling. A Multi-Stage Sampling Procedure Was Adopted For Two Districts One Is Nizamabad And The Second One Is Khammam. Out Of 300 Samples, 150 From Each District Which Covers 4 Sample Villages. There Are 8 Sample Villages In The Two Districts. For The Present Study, 40 Respondents From Village-1 And Village -4 And 35 Respondents From Village - 2 And Village - 3 In Both The Districts Of Telangana Region Are Chosen.

There Are 300 Number Of Sample Respondents Covered 150 From Each District. There Are Four Sugar Factories Covered In The Sample Area. In Each Factory Area, There Are 75 Farmers Who Are Associated With The Sugar Factories. In Each Sugar Factory, There Are 75 Respondents Which Are Spread In Two Sample Villages. The Distributions Of Sample Respondents Are 40 In V1and 35 In V2 Respectively. 


\section{Statistical Tools Used:}

The Data Collected From Field Investigation Were Coded And Then It Was Processed For Simple Frequency Counts, Cross-Tabulations. Simple Statistical Techniques Like Percentages And Averages Are Applied To Find Out Intra And Inter Sample Area And Farm Size Wise Data Comparisons. However, The Farm Management Of The Field Data Pertaining To The Main Crop Of Sugarcane Was Analyzed By Using Statistical Tools Of Percentages, Averages And The Simple Correlation.

\section{Cost Of Cultivation:}

In View Of High Requirements Of Labour, Irrigation, Fertilizers And Pesticides And The Inevitability Of Time Found Transportation The Cost Of Production Is Much Higher Than Other Crops. The Expenditure Involved In Various Stages From Ploughing To The Maturity Of Crop Is Fixed Cost. The Expenditure Measured On Harvesting And Transport Is Variable Cost. Though The Variable Cost Is Related To The Quantity Of Yield, The Fixed Cost Remains The Same Irrespective Of The Quantity Of Yield. This Implies The Farmers Have To Incur A Compulsory Minimum Of Rs. 15,000/- To 20,000/- Per Acre Irrespective Of The Yields. This Is A Peculiar Problem Encountered By The Sugarcane Growers When Compared To The Other Crops, Where Fixed Cost Is Low Compared To Sugarcane. Though The Farmers Are Realized The Advantages Of Modern Means Of Harvesting They Are Still Unable To Modernize Their Harvesting Methods As They Are Not Suitable For Local Conditions.

Among The Production Factors, Labour Expenditure Is Occupies A Lion Share In The Cultivation Of Sugarcane Per Acre. The Other Expenditures Are Transport, Expenditure On Modern Inputs Like Fertilizers And Pesticides, Tractors Etc, Plantation Including Seed And Cultivation (Preparation Of Land) Are Respectively. The Size And The Cost Of Cultivation Is Vary From Different Farm-Size In The Both The Sample Districts. The Cost Of Cultivation Is The Highest In Large Farmers (L.F) Category From Nizamabad District And Medium Farmers Category (Med F) Are In The Both The Sample Districts Due To Involvement Of Won Labour And High Range Use Of Traditional Inputs. Surprisingly The Cost Of Labour Is More In Nizamabad Than Khammam Irrespective Of Their Farm Size, Due To The Coverage Of Urbanization In Nizamabad Than The Khammam District; The Wage Rates Are More In Nizamabad And At The Same Time The Sample Villages Are Very Near To The Town Of Nizamabad It Is The Radios Of $10 \mathrm{Km}$ Only Whereas In Khammam All The Sample Villages Are Around 40 To $100 \mathrm{Km}$ To The District Headquarter Of Khammam Town. The Present Paper Would Like To Analyze The Cost Of Cultivation Per Acre In Different Farm-Sizes Of Sugarcane Production And At The Same Time A Simple Correlation In Between Labour And Capital Is Also Examined In The Present Article.

Table -1a Particulars Of Total Expenditure: Nizamabad (Plantation To Marketing Per Acre In Rs)

\begin{tabular}{|c|c|c|c|c|c|}
\hline $\begin{array}{c}\text { Sugarcane } \\
\text { Operations }\end{array}$ & $\begin{array}{c}\text { Marginal } \\
\text { Farmers }\end{array}$ & $\begin{array}{c}\text { Small } \\
\text { Farmers }\end{array}$ & $\begin{array}{c}\text { Medium } \\
\text { Farmers }\end{array}$ & $\begin{array}{c}\text { Large } \\
\text { Farmers }\end{array}$ & Total Average \\
\hline Cultivation & 1686 & 1721 & 1844 & 1942 & 1768 \\
& $(5.45)$ & $(5.46)$ & $(5.53)$ & $(5.69)$ & $(5.52)$ \\
\hline Plantation & 3364 & 3196 & 3448 & 3533 & 3375 \\
& $(10.87)$ & $(10.14)$ & $(10.34)$ & $(10.35)$ & $(10.53)$ \\
\hline Irrigation & 1952.5 & 1916.5 & 2059 & 2344 & 1914 \\
& $(6.31)$ & $(6.08)$ & $(6.17)$ & $(6.87)$ & $(5.97)$ \\
\hline Modern Inputs & 4951 & 4661 & 5637 & 6500 & 5259 \\
& $(16.00)$ & $(14.79)$ & $(16.90)$ & $(19.04)$ & $(16.41)$ \\
\hline Labour & 13503 & 14489 & 14868 & 14275 & 14222 \\
& $(43.65)$ & $(45.97)$ & $(44.57)$ & $(41.82)$ & $(44.37)$ \\
\hline Transport & 5478 & 5532 & 5502 & 5541 & 5512 \\
Expenditure & $(17.71)$ & $(17.55)$ & $(16.49)$ & $(16.23)$ & $(17.20)$ \\
\hline Total & $\mathbf{3 0 9 3 5}$ & $\mathbf{3 1 5 1 6}$ & $\mathbf{3 3 3 5 8}$ & $\mathbf{3 4 1 3 5}$ & $\mathbf{3 2 0 5 0}$ \\
Expenditure & $(\mathbf{1 0 0 . 0 0})$ & $\mathbf{( 1 0 0 . 0 0 )}$ & $\mathbf{( 1 0 0 . 0 0})$ & $(\mathbf{1 0 0 . 0 0})$ & $(\mathbf{1 0 0 . 0 0})$ \\
\hline Interest & 3712 & 3782 & 4003 & 4096 & 3846 \\
\hline Grand Total & $\mathbf{3 4 6 4 7}$ & $\mathbf{3 5 2 9 7}$ & $\mathbf{3 7 3 6 1}$ & $\mathbf{3 8 2 3 1}$ & $\mathbf{3 5 8 9 6}$ \\
\hline
\end{tabular}

Table -1b Particulars Of Total Expenditure: Khammam (Plantation To Marketing Per Acre In Rs)

\begin{tabular}{|c|c|c|c|c|c|}
\hline Sugarcane Operations & $\begin{array}{c}\text { Marginal } \\
\text { Farmers }\end{array}$ & $\begin{array}{c}\text { Small } \\
\text { Farmers }\end{array}$ & $\begin{array}{c}\text { Medium } \\
\text { Farmers }\end{array}$ & $\begin{array}{c}\text { Large } \\
\text { Farmers }\end{array}$ & Total Average \\
\hline Cultivation & 2277 & 2646 & 2657 & 1250 & 2207.5 \\
& $(7.51)$ & $(8.15)$ & $(7.66)$ & $(3.45)$ & $(6.63)$ \\
\hline Plantation & 3667 & 3656 & 4063 & 3500 & 3863 \\
& $(12.09)$ & $(11.26)$ & $(11.71)$ & $(9.66)$ & $(11.61)$ \\
\hline Irrigation & 1841 & 1451 & 1511 & 2035 & 1449 \\
& $(6.07)$ & $(4.47)$ & $(4.36)$ & $(5.62)$ & $(4.35)$ \\
\hline Modern Inputs & 5116 & 5161 & 5227 & 5718 & 5222 \\
& $(16.87)$ & $(15.89)$ & $(15.07)$ & $(15.79)$ & $(15.69)$ \\
\hline
\end{tabular}


Input Use And Cost Of Cultivation Of Sugarcane - A Study In Telangana Region Of Andhra Pradesh

\begin{tabular}{|c|c|c|c|c|c|}
\hline Labour & $\begin{array}{c}11508 \\
(37.94)\end{array}$ & $\begin{array}{c}13078 \\
(40.26)\end{array}$ & $\begin{array}{c}13820 \\
(39.84)\end{array}$ & $\begin{array}{c}15150 \\
(41.83)\end{array}$ & $\begin{array}{c}13423 \\
(40.33)\end{array}$ \\
\hline Transport Expenditure & $\begin{array}{c}5925 \\
(19.53)\end{array}$ & $\begin{array}{c}6491 \\
(19.98)\end{array}$ & $\begin{array}{c}7407 \\
(21.36)\end{array}$ & $\begin{array}{c}8566 \\
(23.65)\end{array}$ & $\begin{array}{c}7117 \\
(21.38)\end{array}$ \\
\hline Total Expenditure & $\begin{array}{c}30334 \\
(100.00)\end{array}$ & $\begin{array}{c}32483 \\
(100.00)\end{array}$ & $\begin{array}{c}34685 \\
(100.00)\end{array}$ & $\begin{array}{c}36219 \\
(100.00)\end{array}$ & $\begin{array}{c}33281 \\
(\mathbf{1 0 0 . 0 0})\end{array}$ \\
\hline Interest & 3640 & 3898 & 4162 & 4346 & 3994 \\
\hline Grand Total & 33974 & 36381 & 38848 & 40565 & 37275 \\
\hline
\end{tabular}

Source: Field Survey

In Nizamabad District, The Respondent Farmers Are Irrespective Of Their Farm Size Incurred The Highest Share Of The Total Expenditure On Labour. The Total Expenditure And Interest Are Increasing In Very Category Form Marginal Farmers To Large Farmers. The Average Expenditure Of Marginal Farmers And Small Farmers Category Is Less Than The District Average Whereas In Medium Farmers And Large Farmers Category The Average Expenditure Is More Than The District Averages. With Regard To Modern Inputs, The Expenditure Is The Highest In Large Farmers Category, (Rs. 6500/-) And The Lowest In Small Farmers (Rs. 4661/-). In The Aspect Of Labour The Average Expenditure Is The Highest In Medium Farmers (Rs. 14868) And The Lowest Is In Marginal Farmers (Rs. 13503/-) Because The Highest Involvement Of Family Labour In The Marginal Farmers Category. The Expenditure On Transport Is The Highest From Large Farmers (Rs. 5541/-) And The Lowest Is Marginal Farmers It Is (Rs.5478/-) The Expenditure On Irrigation Is The Highest From Large Farmers Is Rs 2344/- And The Lowest Is Small Farmers Category Is Rs. 1916/-. In The Large Farmers Category Expenditure On Seed Cane Reported As The Highest (Rs. 3533/- And In Small Farmers Category Is Reported As The Lowest (Rs. 3196/-), The Expenditure On Tilling And Internal Cultivation Is Reported As The Lowest From Marginal And The Highest Is From Large Farmers Categories Are Rs. 1686/- And Rs. 1942/- Due To The Little Involvement Of Family Labour From The Large Farmers Category (Table 1a)

The Sugarcane Growers In Khammam District Are Incurred The Highest Share Of The Total Average Expenditure On Human Labour. The Total Average Expenditure And Interest Are Increasing In Every Category From Lowest Largest Categories. The Average Total Expenditure In Marginal And Small Categories Is Less Than District Averages Whereas In Medium And Large Categories Are More Than The Whole District Average Expenditure. With Regard To Modern Tools The Average Expenditure Is Highest In Large Farmers And The Lowest Is Marginal Farmers Category. The Average Expenditure Is Highest On Labour In Big Farmers (Rs.15150) And The Lowest In Marginal Farmers Category (Rs.11508/-), Because Of The Highest Involvement Of Own Labour In Marginal Farmers Category. The Expenditure On Transport Is Highest In Large Farmers Category (Rs.8566) And Lowest In Marginal Farmers Category (Rs.5925) As Most Of The Respondents In Marginal Farmers Category Has Involved The Transport Activities At First Spell (Field To Road Point) With Their Own Bullock Carts. The Irrigation Expenditure Is More From Large Category (Rs. 2035/-) And The Lowest Is From Small Category (Rs. 1451/- ), The Expenditure On Seed Cane Is The Highest In The Category Of Medium Farmers It Is Reported As (Rs. 4063/-) And The Lowest Is Reported As (Rs. 3500/-) From Large Farmers Category. In The Aspect Of Tilling And Internal Cultivation Per Acre Is Reported As The Highest In Marginal Farmers Category And The Lowest Is From Large Farmers Category. Because The Majority Of Marginal Farmers Are Depend On Hired Cultivators And The Large Farmers Are Based On Own Tractors It Is The Main Causes For The Highest And Lowest Cultivation Cost Per Acre In The District Of Khammam. (Table 1b)

The Researcher Observed In The Field Study That The Sugarcane Growers Are Getting Fifty Per Cent Of Loan From Sugar Factories Through Institutional Credit Facilities And The Remaining Credit Facilities Are From Government Agencies And Other Sources. Therefore An Average Of 12 Per Cent Of Interest Is Calculated And Included In The Total Average Expenditure Incurred On Sugarcane Production.

Thus, The Comparative Study Of These Districts Reveal That In Nizamabad District The Average Expenditure Per Acre On Ploughing, Seed Cane And Transport Is Less Than Khammam District, But The Expenditure On Irrigation Labour And Modern Inputs Are Higher In Nizamabad Than Khammam District. 
Table. No 2 Particulars Of Total Expenditure: (Plantation To Marketing Per Acre In Rs)

\begin{tabular}{|c|c|c|c|c|c|c|c|c|c|c|}
\hline $\begin{array}{l}\text { Sugarcane } \\
\text { Operations }\end{array}$ & \multicolumn{2}{|c|}{ Marginal Farmers } & \multicolumn{2}{|c|}{$\begin{array}{c}\text { Small } \\
\text { Farmers } \\
\end{array}$} & \multicolumn{2}{|c|}{$\begin{array}{l}\text { Medium } \\
\text { Farmers }\end{array}$} & \multicolumn{2}{|c|}{$\begin{array}{c}\text { Large } \\
\text { Farmers } \\
\end{array}$} & \multicolumn{2}{|c|}{$\begin{array}{c}\text { Total } \\
\text { Average } \\
\end{array}$} \\
\hline$\frac{\text { Sample }}{\text { Districts }}$ & $\underline{\mathrm{Nmz}}$ & $\underline{\mathrm{Kmm}}$ & $\underline{\mathrm{Nmz}}$ & $\underline{\mathrm{Kmm}}$ & $\underline{\mathrm{Nmz}}$ & $\underline{\mathrm{Kmm}}$ & $\underline{\mathrm{Nmz}}$ & $\underline{\mathrm{Kmm}}$ & $\underline{\mathrm{Nmz}}$ & $\underline{\mathrm{Kmm}}$ \\
\hline Cultivation & 1686 & 2277 & 1721 & 2646 & 1844 & 2657 & 1942 & 1250 & 1768 & 2207.5 \\
\hline Plantation & 3364 & 3667 & 3196 & 3656 & 3448 & 4063 & 3533 & 3500 & 3375 & 3863 \\
\hline Irigation & 1952.5 & 1841 & 1916.5 & 1451 & 2059 & 1511 & 2344 & 2035 & 1914 & 1449 \\
\hline Modem Inputs & 4951 & 5116 & 4661 & 5161 & 5637 & 5227 & 6500 & 5718 & 5259 & 5222 \\
\hline Labour & 13503 & $\begin{array}{c}1150 \\
8\end{array}$ & 14489 & $\begin{array}{c}1307 \\
8\end{array}$ & 14868 & $\begin{array}{c}1382 \\
0\end{array}$ & 14275 & $\begin{array}{c}1515 \\
0\end{array}$ & 14222 & 13423 \\
\hline Transport Exp & 5478 & 5925 & 5532 & 6491 & 5502 & 7407 & 5541 & 8566 & 5512 & 7117 \\
\hline Total & 30935 & $\begin{array}{c}3033 \\
4\end{array}$ & 31516 & $\begin{array}{c}3248 \\
3\end{array}$ & 33358 & $\begin{array}{c}3468 \\
5\end{array}$ & 34135 & $\begin{array}{c}3621 \\
9\end{array}$ & 32050 & 33281 \\
\hline Interest & 3712 & 3640 & 3782 & 3898 & 4003 & 4162 & 4096 & 4346 & 3846 & 3994 \\
\hline Grand Total & 34647 & $\begin{array}{c}3397 \\
4\end{array}$ & 35297 & $\begin{array}{c}3638 \\
1\end{array}$ & 37361 & $\begin{array}{c}3884 \\
8\end{array}$ & 38231 & $\begin{array}{c}4056 \\
5\end{array}$ & 35896 & 37275 \\
\hline Correlation & \multicolumn{2}{|c|}{0.9985} & \multicolumn{2}{|c|}{0.9982} & \multicolumn{2}{|c|}{0.9979} & \multicolumn{2}{|c|}{0.9974} & \multicolumn{2}{|c|}{0.9986} \\
\hline
\end{tabular}

The Table - 2 Shows That The Correlation Values Of The Sample Districts In Various Categories Of Sugarcane Growers. There Is A Strong Relation In Between The Both Sample Districts And As Well As Among The All Categories Of Sugarcane Growers.

Table - 3 Particulars Of Correlation On Expenditure.

\begin{tabular}{|c|c|c|c|c|c|c|}
\hline Sample & \multicolumn{3}{|c|}{ nizamabad District } & \multicolumn{3}{|c|}{ khammam District } \\
\hline Category & $\begin{array}{l}\text { Expenditure On } \\
\text { Labour }\end{array}$ & $\begin{array}{l}\text { Expenditure } \\
\text { On Capital }\end{array}$ & $\begin{array}{c}\text { Total } \\
\text { Expenditure }\end{array}$ & $\begin{array}{l}\text { Expenditure On } \\
\text { Labour }\end{array}$ & $\begin{array}{c}\text { Expenditure On } \\
\text { Capital }\end{array}$ & $\begin{array}{c}\text { Total } \\
\text { Expenditure }\end{array}$ \\
\hline M.F & 13503 & 17431 & 30934 & 11508 & 18826 & 30334 \\
\hline S.F & 14489 & 17026 & 31515 & 13078 & 19405 & 32483 \\
\hline Med.F & 14868 & 18490 & 33358 & 13820 & 20865 & 34685 \\
\hline L.F & 14275 & 19860 & 34135 & 15150 & 21069 & 36219 \\
\hline Total & 14222 & 17828 & 32050 & 13423 & 19858 & 33281 \\
\hline \multirow[t]{2}{*}{ Correlation } & \multicolumn{2}{|c|}{0.2406} & & \multicolumn{2}{|c|}{0.9246} & \\
\hline & \multicolumn{2}{|c|}{0.5797} & & \multicolumn{2}{|c|}{0.9866} & 744 \\
\hline
\end{tabular}

\section{Source: Field Survey}

In The Sugarcane Production, The Production Factors Are Broadly Considered In To Two Factors I.E. Labour And Capital. The Above Table - 3 Shows The Expenditure On Both The Factors In Sugarcane Production Per Acre. The Table Is Also Provided The Simple Correlation Values Between Labour And Capital, Labour And Total Expenditure And Capital And Total Expenditure. There Is A Strong Correlation In Between Labour And Capital In Khammam District It Is 0.92, Whereas In Nizamabad District It Is Very Weak 0.24 Only. The Correlation Values In Between Labour And Total Expenditure Is 0 .57. It Shows The General Relation In Nizamabad But In Khammam It Is Strong Relation It Is 0.98. The Relation Between Capital And Total Expenditure There Is A Strong Relation In Both The Sample Districts I.E. 0.93 In Nizamabad And 0.97 In Khammam District. It Is Observed That There Is A Strong Correlation In Khammam District In The Above Said Factors Than Nizamabad District.

The Table - 4 Depicts That The Correlation Values Of The Production Of The Sugarcane Both Sample Districts With Regard To Labour, Capital And The Total Expenditure. There Is A Strong Relation Between Total Expenditure Followed By Capital And Labour I.E. 0.97, 0.86 And 0.62. The Correlation Is Very Strong Between Total Expenditure Of Khammam And Total Expenditure Of Nizamabad Districts Than The Other Aspects. Whereas In The Aspect Of Labour, Reported As The Low Correlation Values Than The Capital And Total Expenditure.

Table - 4 Particulars Of Correlation Values Of The Production Factors

\begin{tabular}{|c|c|c|c|c|c|c|}
\hline $\begin{array}{c}\text { Sample } \\
\text { District }\end{array}$ & Nizamabad & Khammam & Nizamabad & Khammam & Nizamabad & Khammam \\
\hline Category & Labour & Labour & Capital & Capital & Total & Total \\
\hline M.F & 13503 & 11508 & 17431 & 18826 & 30934 & 30334 \\
\hline S.F & 14489 & 13078 & 17026 & 19405 & 31515 & 32483 \\
\hline Med.F & 14868 & 13820 & 18490 & 20865 & 33358 & 34685 \\
\hline L.F & 14275 & 15150 & 19860 & 21069 & 34135 & 36219 \\
\hline Total & $\mathbf{1 4 2 2 2}$ & $\mathbf{1 3 4 2 3}$ & $\mathbf{1 7 8 2 8}$ & $\mathbf{1 9 8 5 8}$ & $\mathbf{3 2 0 5 0}$ & $\mathbf{3 3 2 8 1}$ \\
\hline
\end{tabular}


Input Use And Cost Of Cultivation Of Sugarcane - A Study In Telangana Region Of Andhra Pradesh

\begin{tabular}{|c|c|c|c|}
\hline Correlation & $\mathbf{0 . 6 2 4 3}$ & $\mathbf{0 . 8 6 9 4}$ & 0.9742 \\
\hline
\end{tabular}

Source: Field Survey

\section{Findings Of The Study}

The Average Total Expenditure Per Acre Increases From Lower To The Higher Categories Of Sugarcane Growers I.E. Marginal Farmers To Large Farmers. This Phenomenon Is The Result Of Three Features (I) The Expenditure On Labour Occupies A Lion Share In The Total Expenditure And So In The Lower Category Of Farmers Where The Involvement Of Own Labour In Various Agricultural Operations Like Plantation, Tying Of Leaves Irrigation Harvesting And Transportation, The Expenditure On Labour Is Less And Ultimately The Total Expenditure Is Also Less. In The Higher Category Of Farmers The Expenditure On Labour And The Total Expenditure Is Higher Due To Absence Of Own Labour. (Ii) The Larger Of Land Holding More The Yielding. As The Total Expenditure Is Directly Proportional To Yielding The Farmers Of Higher Category Incurred More Expenditure. (Iii) The Expenditure Is On Modern Inputs Is Also Increasing From Marginal Farmers To Big Farmers Category.

The Expenditure On Labour Comprises A Significant Share In The Total Expenditure. Labour Is Engaged In Various Operations. The Harvesting Involves More Than 60.00 Per Cent Of The Expenditure On Labour. The Quantum Of And Expenditure On Harvesting Labour Is Directly Prepositional To The Yield. The Expenditure On The Labour Involved In The Other Operations Is More In Nizamabad District Than In Khammam District. The Total Expenditure On Labour Is More In Nizamabad District Than In Khammam District. It Is Noteworthy That The Sugarcane Growers In Khammam District Resort To The Tying Of Leaves Which Involves Labour. This Practice Is Not Found In Nizamabad District. Yet The Total Expenditure On Labour Is Less In Khammam District Than In Nizamabad District Because The Supply Of Labour Is Higher And The Wage Rates Are Lower In Khammam District When Compared To Nizamabad District. In Nizamabad District Some Sugarcane Growers Are Involving Their Own Physical Labour In The Operations Along With The Hired Labour And Those Farmers Included Their Own Wages In Expenditure On Labour.

As Far As Means Of Cultivation Are Concerned Both Traditional And Modern Means I.E. Tractor And Bullocks Are Indispensable In Sugarcane Cultivation. Both These Means Are Either Own Or Rented. For Internal Cultivation For Most Part Marginal Farmers Rely On Own Bullocks And Hired Tractors. On The Other Hand Large Farmers Use Own Tractors And Hired Bullocks. Who Own What And Who Hire What? This Explains The Economic Status Of Sugarcane Cultivation.

The Marginal Farmers And Small Farmers Mostly Practice The Traditional Means Of Cultivation And The Modern Means Of Cultivations Are In The Hands Of Large Farmers As They Require Higher Investment Affordable To Big Farmers Alone.

All The Respondent Farmers Are Revealed That The Free Electricity Is Very Helpful To Them. All The Growers Have Their Own Pump Sets And Some Oil Engines For Irrigation. The Example Of The Optimum Utilization Of Land And Water Is Also Seen In The Field Observation. Some Farmers Are Purchasing The Ground Water From Their Neighbours Bore Wells When The Water From Their Own Bore Wells Is Not Sufficient. These Payments Range From Rs. 500-1000 Per Acre With This The Expenditure On Irrigation In Such Cases Exceeds Rs. 3000 Per Acre.

The Seed Cane Requirement Is 3 To 5 Tonnes Per Acre And The Cost Is Rs. 1000 To 1200 Per Tone. In Case Where The Seed Is Procured From The Factory Or Other Farmers, This Cost Is Escalated To The Tune Of Transport Expenditure.

The Expenditure On Fertilizers Is Less In Khammam District Than In Nizamabad District. Because Of Subsidized Fertilizers Supplied From The Factories And Optimum Consumption Of Indigenous Manure Is More In Khammam District.

In Khammam District Though The Fertilizers Of Consumption Is More, The Expenditure Is Less Than In Nizamabad District Because Of Subsidized Fertilizers Provided By The Factories.

Thus The Fore Going Analysis On Input Use And Cost Of Cultivation On Sugarcane Production Indicates That, The Availability Of Inputs Is Needed To Get More Production. The Study Result Shows That, The Input Use And Cost Of Cultivation Are More In Case Of Large Farmers. The Expenditure On Cultivation And Input Use Are Less In Case Of Marginal And Small Farmers. It Dose Not Mean The Expenditure Is Low But The Own Family Labour Contribution Of Own Transportation And Concentration Of Labour Force Are The Responsible Factors For The Low Level Of Expenditure. If The Policy Of The Governments Encourage The Small And Marginal Farmers Through Institutional Agencies, The Gains From The Sugarcane Cultivation Will Be More Fore Small And Marginal Farmers To Into Their Productivity, Efficiency And The Sustainable Growth Is Possible In The Long Run Period. 


\section{References}

[1]. Dutt And Kpm Sundaram Indian Economy(2005), Chand Company

[2]. K. Madhavarao Ph.D Thesis Of Kakatiya University Warangal 2006. Pp $12-18$

[3]. $\quad$ R. L. Yadav And R. S. Vema “Cane Sugar Production” Yojana Septmber 2006, Pp 53

[4]. Isma (2013) Indian Sugar Industry

[5]. Sugar India Yearbook - 2013 Sisma

[6]. R. L. Yadav And R. S. Vema "Cane Sugar Production” Yojana Septmber 2006, Pp 53

[7]. R. L. Yadav And R. S. Vema Ibid., P.53.

[8]. R. L. Yadav And R. S. Vema Ibid., P. 53

[9]. R. L. Yadav And R. S. Vema Ibid., P.54

[10]. World Bank (2006) Development Research Group Trade Team April 2006 P No 1) Policy Research Working Paper 3874, The World Bank Development Research Group Trade Team April 2006 P No 1

[11]. A. Narayanamoorthy (2005) "Economics Of Drip Irrigation In Sugarcane Cultivation: A Case Study Of A Farmer From Tamil Nadu",Indian Journal Of Agricultural Economics Volume 60 No 2 April -June 2005 P No 235

[12]. C.H. Hanumantha Rao, (1965) "Agricultural Production Functions, Costs And Returns In India", Asia Publishing House, New Delhi

[13]. S.K. Chkravarthy “A Recent Change In Saving Investment Direction Of The Small Cultivation In West Bangal” (Case Studies In Hoogly Dist.) Agricultural Situation In India; Vol. Xxvii No.4 Oct - Dec. 1972. P. 64-74

[14]. R.B. Parthasarathy And K.S. Satyanarayan "Impact Of Increase Input Prices On Profitability In Sugarcane Production Application Of Break Even Analysis", The Indian Journal Of Agricultural Economics, Vol. 31, No 3, July - Sept, 1976, Page No $85-89$.

[15]. V.K.R.V. Rao “Agricultural Development And Social Justice”, Co-Operative New Digest, August 1978, P.45.

[16]. 16. C.H. Hanumantha Rao "Technological Change And Distribution Of Gains In Indian Agriculture", Asia's Pub. House, Delhi, 1979, P.52

[17]. K.S.Pradeep And E.G.Heady "Size Productivity And Returns To Scale - A Case Study In Birhhum District" -Agricultural Situation In India, June, 1983, Page 141-145.

[18]. R.K. Patel And A.C.Gangwar "Production Of Potential For Farm Income And Employment In Dry Farming Area Of Haryana" Agricultural Situation In India, June, 1983 P. 135-139.

[19]. District Hand Book Nizamabad And Khammam 2006-07, Chief Planning Office, Nizamabad And Khammam Districts. 